Molecular Panbiogeography of the Tropics 


\section{SPECIES AND SYSTEMATICS}

www.ucpress.edu/go/spsy

The Species and Systematics series will investigate fundamental and practical aspects of systematics and taxonomy in a series of comprehensive volumes aimed at students and researchers in systematic biology and in the history and philosophy of biology. The book series will examine the role of descriptive taxonomy, its fusion with cyber-infrastructure, its future within biodiversity studies, and its importance as an empirical science. The philosophical consequences of classification, as well as its history, will be among the themes explored by this series, including systematic methods, empirical studies of taxonomic groups, the history of homology, and its significance in molecular systematics.

Editor in Chief: Malte C. Ebach (University of New South Wales, Australia)

Editorial Board

Sandra Carlson (University of California, Davis, USA)

Marcelo R. de Carvalho (University of São Paulo, Brazil)

Darren Curnoe (University of New South Wales, Australia)

Christina Flann (Netherlands Centre for Biodiversity Naturalis, The Netherlands)

Anthony C. Gill (University of Sydney, Australia)

Lynne R. Parenti (Smithsonian Institution, USA)

Olivier Rieppel (The Field Museum, Chicago, USA)

John S. Wilkins (University of Sydney, Australia)

Kipling Will (University of California, Berkeley, USA)

David M. Williams (The Natural History Museum, London, UK)

René Zaragüeta i Bagils (University of Paris 6, France)

University of California Press Editor: Charles R. Crumly 


\title{
Molecular Panbiogeography of the Tropics
}

\author{
Michael Heads
}

甲

UNIVERSITY OF CALIFORNIA PRESS

Berkeley · Los Angeles • London 
University of California Press, one of the most distinguished university presses in the United States, enriches lives around the world by advancing scholarship in the humanities, social sciences, and natural sciences. Its activities are supported by the UC Press Foundation and by philanthropic contributions from individuals and institutions. For more information, visit www.ucpress.edu.

Species and Systematics, Vol. 4

For online version, see www.ucpress.edu.

University of California Press

Berkeley and Los Angeles, California

University of California Press, Ltd.

London, England

(C) 2012 by The Regents of the University of California

Library of Congress Cataloging-in-Publication Data

Heads, Michael J.

Molecular panbiogeography of the tropics / Michael Heads.

p. $\quad$ cm.-(Species and systematics; v. 4)

Includes bibliographical references and index. ISBN 978-0-520-27I96-8 (cloth : alk. paper)

1. Biogeography-Tropics. 2. Biology-

Classification-Molecular aspects. 3. Variation (Biology)-Tropics. I. Title.

$\mathrm{QH} 84 \cdot 5 . \mathrm{H}_{43} 2 \mathrm{OI} 2$

$578.01^{\prime} 2-\mathrm{dc} 23$

2011016690

$\begin{array}{llllllll} & \text { I9 } 8 & \text { I7 } & \text { I6 } & \text { I5 } & \text { I4 } & \text { I3 } & \text { I2 }\end{array}$

$\begin{array}{llllllllll}\text { IO } & 9 & 8 & 7 & 6 & 5 & 4 & 3 & 2 & \text { I }\end{array}$

The paper used in this publication meets the minimum requirements of ANSI/NISO Z39.48-I992 (R I997) (Permanence of Paper). $\infty$

Cover photograph: Mist rising from the Borneo rainforest. Photo by Rhett A. Butler, mongabay.com. 